\title{
Pengaruh Profitabilitas, Free Cash Flow, dan Ukuran Perusahaan pada Nilai Perusahaan
}

\author{
Putu Ayu Widiastari ${ }^{1}$ \\ Gerianta Wirawan Yasa ${ }^{2}$
}

${ }^{1}$ Fakultas Ekonomi dan Bisnis Universitas Udayana (Unud), Bali, Indonesia
email: ayuwidiastari08@ gmail.com/ Telp: +6287760125985
${ }^{2}$ Fakultas Ekonomi dan Bisnis Universitas Udayana (Unud), Bali, Indonesia

\begin{abstract}
ABSTRAK
Tujuan perusahaan bukan hanya untuk memperoleh keuntungan, namun juga berorientasi pada kemakmuran pemegang saham melalui peningkatan nilai perusahaan. Nilai perusahaan dicerminkan dari harga sahamnya. Penelitian ini bertujuan untuk mengetahui pengaruh profitabilitas, free cash flow, dan ukuran perusahaan pada nilai perusahaan. Penelitian ini dilakukan pada perusahaan consumer goods yang terdaftar di Bursa Efek Indonesia selama periode 2011-2015. Jumlah sampel yang digunakan sebanyak 24 perusahaan dengan metode pengambilan sampel menggunakan metode non probability sampling. Metode pengumpulan data yang digunakan adalah observasi non partisipan. Teknik analisis yang digunakan adalah analisis regresi linear berganda. Berdasarkan hasil analisis ditemukan bahwa profitabilitas dan ukuran perusahaan mempunyai pengaruh positif pada nilai perusahaan. Sementara free cash flow tidak berpengaruh pada nilai perusahaan.
\end{abstract}

Kata Kunci: profitabilitas, free cash flow, ukuran perusahaan, nilai perusahaan

\section{ABSTRACT}

The company's goal is not only to gain profit, but also to shareholder prosperity through enhancing corporate value. Company value is reflected from its share price. This study aims to determine the effect of profitability, free cash flow, and firm size on the value of the company. This study was conducted on consumer goods companies listed on the Indonesia Stock Exchange during the period 2011-2015. The number of samples used are 24 companies with sampling method using non probability sampling method. Data collection method used is non participant observation. The analysis technique used is multiple linear regression analysis. Based on the results of the analysis found that the profitability and size of the company have a positive influence on the value of the company. While free cash flow does not affect the value of the company.

Keywords: profitability, free cash flow, company size, corporate value

\section{PENDAHULUAN}

Tujuan perusahaan bukan hanya berorientasi pada memaksimalkan keuntungan saja, namun perusahaan juga berfokus pada meningkatkan kemakmuran pemilik atau para pemegang saham melalui peningkatan nilai perusahaan (Salvatore, 2005). Nilai perusahaan adalah harga saham yang bersedia dibayar oleh calon pembeli (pemegang saham atau investor) apabila perusahaan dijual. Nilai suatu 
perusahaan sangatlah penting bagi pemilik perusahaan karena hal tersebut merupakan persepsi investor terhadap tingkat keberhasilan kinerja perusahaan yang dikaitkan dengan harga saham. Harga saham memiliki korelasi yang positif terhadap nilai perusahaan karena harga saham yang tinggi maka akan meningkatkan nilai perusahaan. Suharli (2006) menyatakan bahwa harga saham yang meningkat akan meningkatkan nilai perusahaan yang ditandai dengan tingkat pengembalian investasi yang tinggi kepada pemegang saham. Nilai perusahaan yang tinggi akan membuat pasar percaya pada kinerja perusahaan dan yang lebih penting bahwa perusahaan memiliki prospek yang baik di masa mendatang.

Terdapat beberapa cara yang digunakan untuk mengukur nilai perusahaan, salah satunya dengan menggunakan Tobin's $Q$. Rasio Tobin's $Q$ digunakan untuk melihat bagaimana reaksi pasar atau penilaian pasar terhadap perusahaan dari berbagai aspek yang dilihat oleh pihak luar termasuk investor. Menurut Smithers dan Wright (2008:40), Tobin's $Q$ memiliki keunggulan seperti Tobin's $Q$ mencerminkan aset perusahaan secara keseluruhan, mencerminkan sentimen pasar (misalnya analisis dilihat dari prospek perusahaan atau spekulasi), mencerminkan modal intelektual perusahaan.

Meningkatkan laba dan nilai perusahaan merupakan hal yang saling berkaitan karena merupakan hal yang penting bagi kelangsungan hidup perusahaan. Nilai perusahaan juga dipengaruhi oleh besar kecilnya profitabilitas yang dihasilkan. Menurut Wiagustini (2010:86), profitabilitas adalah kemampuan perusahaan menghasilkan laba atau ukuran efektivitas pengelolaan manajemen 
perusahaan. Para investor yang menanamkan investasinya pada suatu perusahaan bertujuan untuk mendapatkan return. Semakin tinggi profit yang mampu dihasilkan oleh perusahaan, maka semakin besar harapan investor untuk mendapatkan return yang tinggi dari perusahaan.

Profitabilitas yang tinggi menunjukkan prospek perusahaan dimasa mendatang akan diprediksi menguntungkan oleh investor sehingga investor akan tertarik merespon sinyal positif yang diberikan, sehingga nilai perusahaan meningkat (Kusumayanti, 2016). ROA (Return On Assets) digunakan dalam penelitian ini untuk mengukur variabel profitabilitas. ROA memiliki keunggulan seperti manajemen menjadi menitikberatkan perhatiannya pada laba yang maksimal, analisis ROA digunakan perusahaan dalam hal perencanaan, sebagai alat pengukur prestasi manajemen dalam efisiensi penggunaan modal yang menyeluruh.

Chen dan Chen (2011), Pratama (2016), dan Garmayuni (2015) melakukan penelitian dan memperoleh hasil bahwa profitabilitas yang diproksikan dengan ROA memiliki pengaruh positif terhadap nilai perusahaan karena ROA yang semakin tinggi maka kemampuan perusahaan membayar dividen juga tinggi yang akan menarik investor sehingga nilai perusahaan akan meningkat melalui peningkatan harga saham. Namun, hasil berbeda diperoleh dari penelitian yang dilakukan oleh Yastini (2015) dan Herawati (2013) dimana ROA tidak berpengaruh terhadap nilai perusahaan.

Selain profitabilitas, arus kas bebas (free cash flow) juga merupakan salah satu faktor yang dapat berpengaruh pada nilai perusahaan. Menurut Brigham dan 
Houston (2006) free cash flow adalah arus kas bebas yang dimiliki perusahaan yang diperuntukkan untuk dapat dibagikan kepada pemegang saham maupun didistribusikan kepada kreditur diluar arus kas yang dipergunakan perusahaan untuk menjalankan operasinya dan juga dijadikan indikator untuk mengukur kemampuan perusahaan dalam mengembalikan keuntungan para pemegang saham. Perusahaan yang memiliki tingkat arus kas bebas tinggi cenderung akan mempunyai return lebih besar dibandingkan perusahaan dengan tingkat arus kas bebas yang rendah (Vogt dan Vu, 2000). Apabila perusahaan ingin memaksimalkan nilai perusahaannya maka free cash flow yang dimiliki harus dibayarkan kepada para pemegang saham dalam bentuk dividen.

Free cash flow yang tinggi akan berdampak pada meningkatnya nilai perusahaan, yang diindikasikan melalui kinerja perusahaan yang tinggi sehingga harga saham perusahaan pun menjadi tinggi (Arfan, 2013). Gregory dan Wang (2010) menemukan bahwa apabila perusahaan memiliki free cash flow yang tinggi maka perusahaan akan menghasilkan return yang lebih baik daripada perusahaan yang memiliki free cash flow yang rendah. Pada prinsipnya, free cash flow yang dimiliki perusahaan digunakan untuk mendanai proyek, membayar utang, dan dibagikan kepada pemegang saham dalam bentuk dividen (Dewi, 2016).

Penelitian yang dilakukan oleh Wang (2010) pada perusahaan go public di Taiwan, free cash flow berpengaruh positif terhadap nilai perusahaan, ini berarti bahwa semakin tinggi free cash flow yang ada di perusahaan maka kinerja perusahaan akan semakin baik. Penelitian lain yang dilakukan oleh Arfan (2013) serta Andini dan Wirawati (2014) memperoleh hasil free cash flow berpengaruh 
positif pada nilai perusahaan. Berbeda dengan Yudianti (2005) dan Naini (2014), serta Arieska dan Gunawan (2011) memperoleh hasil free cash flow tidak berpengaruh pada nilai perusahaan.

Faktor lainnya yang dikatakan dapat mempengaruhi nilai perusahaan adalah ukuran perusahaan, karena semakin besarnya ukuran perusahaan akan mempengaruhi mudahnya perusahaan mendapat sumber pendanaan (Dewi, 2013). Hasil penelitian yang dilakukan Nurhayati (2013) menemukan bahwa dalam membeli saham suatu perusahaan, investor juga mempertimbangkan ukuran perusahaan. Ukuran perusahaan dijadikan patokan dalam menilai kinerja perusahaan, dimana kinerja perusahaan yang bagus akan dapat meningkatkan total aset yang dimiliki sehingga ukuran perusahaan menjadi lebih besar. Perusahaan besar memiliki kecenderungan kondisi yang lebih stabil sehingga investor menjadi tertarik untuk membeli saham perusahaan tersebut yang berdampak pada meningkatnya nilai perusahaan.

Penelitian yang dilakukan oleh Armadi (2016) mendapatkan hasil bahwa ukuran perusahaan berpengaruh positif terhadap nilai perusahaan karena semakin besar ukuran perusahaan maka nilai perusahaannya akan meningkat. Hasil penelitian tersebut didukung oleh penelitian yang dilakukan oleh Analisa (2011) dan Nurhayati (2013). Sementara penelitian yang mendapatkan hasil bertentangan yaitu yang dilakukan oleh Dewi (2013) menemukan hasil bahwa ukuran perusahaan tidak berpengaruh terhadap nilai perusahaan.

Consumer goods merupakan salah satu faktor penting dalam perekonomian karena tingginya kebutuhan dan daya beli masyarakat Indonesia 
sehingga menjadi perhatian menarik bagi dunia bisnis dan investasi. Industri barang konsumsi terdiri dari beberapa subsektor yaitu subsektor makanan dan minuman, rokok, farmasi, kosmetik, dan peralatan rumah tangga. Berikut disajikan dalam tabel indeks harga saham perusahaan consumer goods dari tahun 2010-2015 yang menarik untuk diamati seperti dibawah ini.

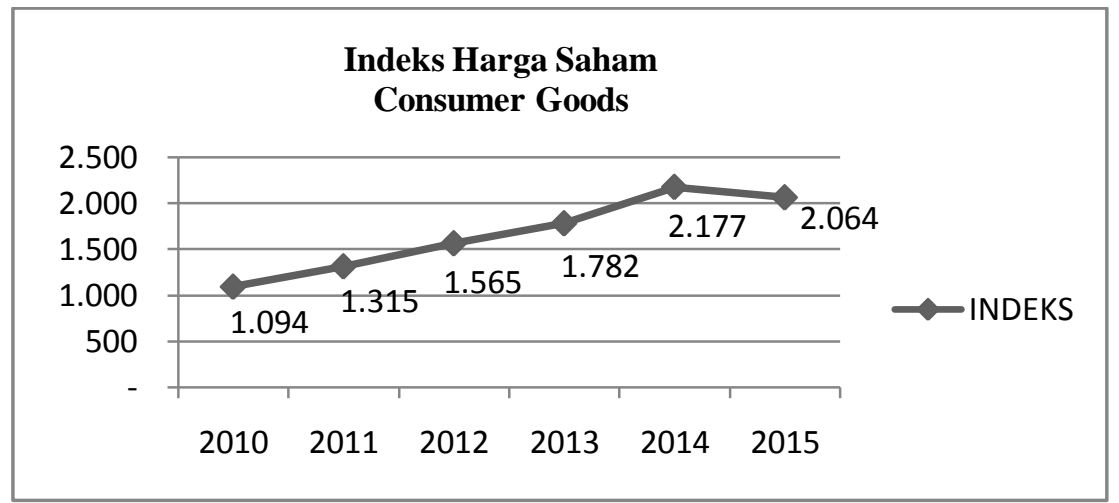

Gambar 1.

Grafik Indeks Harga Saham Perusahaan Consumer Goods Tahun 2010-2015 Sumber: Data diolah 2017

Berdasarkan Gambar 1. diatas dapat dilihat bahwa indeks harga saham perusahaan consumer goods pada tahun 2010 sampai dengan 2014 terlihat adanya peningkatan, namun di tahun 2015 terjadi sedikit penurunan. Indeks harga saham pada tahun 2010 adalah sebesar 1.094 dan terus meningkat pada tahun 2011 hingga tahun 2014 yaitu masing-masing sebesar 1.315, 1.565, 1.782, dan 2.177. Namun, pada tahun 2015 terjadi sedikit penurunan harga saham consumers goods menjadi 2.064. Peningkatan indeks harga saham perusahaan consumers goods yang meningkat menandakan, bahwa perusahaan terus berupaya untuk dapat meningkatkan kinerja perusahaan sehingga mampu meningkatkan nilai perusahaan dan menarik investor. 
Penelitian ini merupakan modifikasi dari penelitian yang dilakukan oleh Rudangga (2016). Hal yang membedakan dari penelitian sebelumnya yaitu Return On Assets (ROA) dipilih menjadi proksi dari profitabilitas karena semakin besar ROA maka semakin efektif perusahaan menggunakan aktivanya untuk beroperasi menghasilkan laba. Sesuai dengan teori sinyal bahwa semakin besar laba maka nilai perusahaan akan meningkat. Selain itu, dalam penelitian ini variabel free cash flow dipilih karena profitabilitas yang tinggi disertai dengan peningkatan free cash flow dapat menjadi good news perusahaan dalam meyakinkan pasar bahwa perusahaan memiliki kinerja yang baik, mampu memberikan return yang tinggi dan memiliki prospek yang baik di masa mendatang. Good news tersebut diharapkan dapat direspon dengan baik oleh investor sehingga dapat meningkatkan nilai perusahaan melalui peningkatan harga saham.

Penelitian ini memiliki tujuan untuk mengetahui pengaruh profitabilitas, free cash flow, dan ukuran perusahaan pada nilai perusahaan. Secara teoritis hasil penelitian ini diharapkan dapat mendukung aplikasi teori sinyal (signalling theory) terkait dengan faktor fundamental meliputi profitabilitas, free cash flow, dan ukuran perusahaan dalam mempengaruhi nilai perusahaan sehingga dapat menambah referensi bagi dunia pendidikan dan pihak-pihak yang berkepentingan dalam menilai suatu perusahaan. Menurut Wolk et al., (2001), teori sinyal menjelaskan alasan perusahaan menyajikan informasi untuk pasar modal terkait dengan aktivitas bisnisnya. Informasi merupakan unsur penting bagi investor dan pelaku bisnis karena menyajikan gambaran tentang kondisi perusahaan pada masa lalu, saat ini, dan masa yang akan datang mengenai kelangsungan hidup suatu 
perusahaan. Informasi yang lengkap, akurat, relevan, dan tepat waktu akan membantu para investor di pasar modal untuk melakukan analisis dalam pengambilan keputusan investasi.

Signalling theory menjelaskan bahwa perusahaan didorong untuk dapat memberikan informasi laporan keuangannya kepada pihak eksternal (investor dan kreditor) untuk mencegah terjadinya asimetri informasi. Informasi yang diberikan perusahaan kepada pihak eksternal diharapkan dapat mengurangi terjadinya asimetri informasi antara pihak internal dan pihak eksternal sekaligus diharapkan dapat meningkatkan nilai perusahaan. Menurut Jogiyanto (2010) informasi yang dipublikasikan sebagai suatu pengumuman akan memberikan sinyal kepada investor. Apabila pengumuman tersebut mengandung nilai yang positif, maka pasar akan merespon dengan baik informasi tersebut sehingga akan terjadi perubahan dalam volume perdagangan dan perubahan harga saham dimana hal tersebut dapat mempengaruhi nilai perusahaan yang tercermin dari peningkatan harga saham perusahaan.

Menurut signalling theory, pelaporan informasi keuangan terkait dengan kinerja perusahaan akan dapat meningkatkan nilai perusahaan. Semakin tinggi laba yang dihasilkan perusahaan akan menunjukkan bahwa kinerja keuangan perusahaan semakin baik dan prospek perusahaan kedepannya menjadi menjanjikan. Selain itu, pertumbuhan ROA akan dapat meyakinkan investor bahwa perusahaan mampu memberikan tingkat return investasi yang tinggi. Hal tersebut ditangkap sebagai sinyal positif oleh investor sehingga akan termotivasi 
untuk meningkatkan transaksi permintaan sahamnya yang akan berdampak pada peningkatan nilai perusahaan.

Ghosh dan Ghosh (2008), Chen dan Chen (2011) serta Dwipayana (2016) memperoleh hasil penelitian yaitu profitabilitas berpengaruh positif pada nilai perusahaan. Berdasarkan teori dan hasil penelitian terdahulu, maka hipotesis yang diajukan dalam penelitian ini adalah.

$\mathrm{H}_{1}$ : Profitabilitas berpengaruh positif terhadap nilai perusahaan.

Free cash flow adalah dana yang dimiliki perusahaan diluar dana untuk modal kerja yang diperuntukkan untuk dapat dibagikan kepada kreditur maupun para pemegang saham (Ross et al., 2000). Menurut signalling theory, profitabilitas yang tinggi merupakan sinyal positif, ditambah lagi perusahaan memiliki free cash flow yang tinggi sehingga hal tersebut akan menambah keyakinan investor bahwa perusahaan mampu memberikan return yang tinggi dalam bentuk dividen. Jensen (1986) dalam Vogt dan Vu (2000) menyatakan bahwa harga saham dari perusahaan dengan free cash flow yang positif seharusnya akan terus mengalami peningkatan, karena manajemen didorong untuk meningkatkan pembayaran kepada pemegang saham. Tingginya free cash flow yang dimiliki di perusahaan akan menunjukkan semakin sehat perusahaan tersebut sebab perusahaan memiliki kas bebas yang tersedia yang dapat menunjukkan bahwa perusahaan dalam kondisi yang baik.

Penelitian yang dilakukan oleh Al Zararee (2014), Tommy (2010), dan Wardani dan Siregar (2009) menunjukkan free cash flow berpengaruh positif 
terhadap nilai perusahaan. Berdasarkan hal tersebut maka hipotesis yang diajukan dalam penelitian ini.

$\mathrm{H}_{2}$ : Free cash flow berpengaruh positif terhadap nilai perusahaan.

Ukuran perusahaan adalah suatu skala atau nilai dimana perusahaan dapat diklasifikasikan besar atau kecilnya berdasarkan total aktiva, total penjualan, nilai saham dan sebagainya. Risqia (2013) menyatakan bahwa ukuran perusahaan adalah tingkat untuk menunjukkan perkembangan perusahaan dalam bisnis. Hal yang sama juga dinyatakan oleh Sujoko dan Soebianto (2007) dalam Kusumayanti (2016) bahwa perkembangan perusahaan ditunjukkan melalui ukuran perusahaan yang besar, hal tersebut akan menarik respon dari para investor secara positif sehingga akan meningkatkan nilai perusahaan.

Menurut signalling theory, semakin besar ukuran perusahaan maka investor akan lebih tertarik untuk membeli sahamnya, sehingga akan meningkatkan permintaan saham perusahaan dan memacu naiknya harga saham perusahaan. Peningkatan tersebut menunjukkan bahwa perusahaan dianggap memiliki nilai yang lebih besar di mata investor (Analisa, 2011). Penelitian yang dilakukan oleh Analisa (2011), Armadi (2016), dan Risqia (2013) membuktikan bahwa ukuran perusahaan berpengaruh positif terhadap nilai perusahan. Berdasarkan teori dan dukungan dari hasil penelitian tersebut, maka hipotesis yang diajukan dalam penelitian ini adalah.

$\mathrm{H}_{3}$ : Ukuran perusahaan berpengaruh positif terhadap nilai perusahaan. 


\section{METODE PENELITIAN}

Desain penelitian menunjukkan pengaruh langsung antara profitabilitas (ROA) dengan nilai perusahaan $(Q)$, free cash flow (FCF) dengan nilai perusahaan $(Q)$, dan ukuran perusahaan (Size) nilai perusahaan $(Q)$. Lokasi penelitian ini yaitu perusahaan-perusahaan consumer goods yang terdaftar di Bursa Efek Indonesia pada periode tahun 2011-2015 dengan mengakses website resmi Bursa Efek Indonesia yaitu www.idx.co.id. Jenis data yang digunakan adalah data kuantitatif dengan sumber data sekunder yaitu laporan keuangan tahunan perusahaan consumers goods yang telah dipublikasikan untuk periode 2011-2015 yang diakses melalui website resmi BEI yaitu www.idx.co.id.

Penelitian ini menggunakan 4 variabel yang terdiri dari varibel bebas yaitu profitabilitas, free cash flow, dan ukuran perusahaan serta variabel terikat yaitu nilai perusahaan. Nilai perusahaan dalam penelitian ini diproksikan dengan Tobin's $Q$. Alasan menggunakan rasio Tobin's $Q$ karena rasio ini juga menggunakan unsur kewajiban yang juga digunakan sebagai dasar perhitungan, sehingga dapat menggambarkan perusahaan secara keseluruhan serta untuk melihat bagaimana reaksi pasar terhadap perusahaan. Rumus Tobin's $Q$ adalah sebagai berikut (Suartawan dan Yasa, 2016) :

$\mathrm{Q}=\frac{\mathrm{MVE}+\mathrm{Debt}}{\mathrm{TA}}$

Keterangan :

$Q \quad=$ Nilai Perusahaan

MVE = Nilai pasar ekuitas (jumlah saham beredar $\mathrm{x}$ closing price)

Debt $=$ Nilai buku hutang

TA $=$ Nilai buku total asset 
Menurut Wiagustini (2010:86) profitabilitas adalah kemampuan perusahaan menghasilkan laba atau ukuran efektivitas pengelolaan manajemen peusahaan. Return On Assets (ROA) dipilih menjadi proksi profitabilitas karena melalui ROA dapat dilihat seberapa efektif perusahaan menghasilkan laba berdasarkan kekayaan yang dimiliki, sehingga semakin besar ROA maka semakin efektif perusahaan menggunakan aktivanya untuk beroperasi yang akan meningkatkan nilai perusahaan. ROA dihitung dengan menggunakan rumus :

ROA $=\underline{\text { Laba Bersih Setelah Pajak }} \times 100 \%$

Free Cash Flow (FCF) merupakan kas yang tersedia dalam perusahaan yang sudah terbebas dari pajak serta biaya-biaya lain dalam perusahaan. FCF diproksikan denga rumus yang dikemukakan oleh Ross et al. (2000) sebagai berikut :

$\mathrm{FCF}=\frac{\mathrm{AKO}-\mathrm{PM}-\mathrm{NWC}}{\text { Total Aset }}$

Keterangan :

$\mathrm{FCF} \quad=$ Free Cash Flow

$\mathrm{AKO}=$ Aliran Kas Operasi perusahaan

$\mathrm{PM} \quad=$ Pengeluaran Modal bersih perusahaan

NWC = Modal Kerja Bersih perusahaan (aset lancar - kewajiban lancar)

Ukuran Perusahaan (Size) merupakan besar kecilnya perusahaan yang dapat diukur melalui besar kecilnya total aset yang dimiliki oleh perusahaan. Rumus ukuran perusahaan :

Size $=\operatorname{Ln}($ Total Aset $)$

Populasi yang digunakan dalam penelitian ini adalah seluruh perusahaan barang konsumsi (consumer goods) yang terdaftar di BEI yaitu sebanyak 33 perusahaan. Sampel dalam penelitian ini ditentukan dengan metode 
nonprobability sampling teknik purposive sampling, yaitu metode penentuan sampel dengan menggunakan kriteria-kriteria tertentu (Sugiyono, 2012:122). Kriteria-kriteria yang digunakan yaitu: 1) Perusahaan consumer goods yang terdaftar secara berturut-turut di BEI dan mempublikasikan laporan keuangannya dari tahun 2011 - 2015; 2) Perusahaan consumer goods tidak mengalami kerugian. Berdasarkan kriteria penentuan sampel tersebut diperoleh sebanyak 24 perusahaan yang memenuhi kriteria dengan waktu pengamatan 5 tahun.

Penelitian ini menggunakan metode pengumpulan data dengan observasi non-partisipan. Metode observasi non-partisipan merupakan teknik pengumpulan data dimana peneliti tidak terlibat secara langsung dalam mendapatkan data melainkan hanya sebagai pengamat independen (Sugiyono, 2012:203). Teknik analisis data yang digunakan adalah analisis regresi linear, dari hasil analisis regresi tersebut dapat diamati Uji $\mathrm{F}$ yaitu untuk menguji apakah model regresi yang telah dibuat layak atau tidak, Uji t (Uji Hipotesis) yaitu mengetahui pengaruh dari masing-masing variabel independen secara parsial terhadap variabel independen, dimana hasil kesimpulannya dapat diambil dengan ketentuan, jika tingkat signifikansi uji $\mathrm{t} \leq \alpha=0,05$ maka $\mathrm{H}_{0}$ ditolak dan $\mathrm{H}_{1}$ diterima, artinya variabel independen berpengaruh terhadap variabel dependen. Sebaliknya jika tingkat signifikansi uji $\mathrm{t}>\alpha=0,05$ maka $\mathrm{H}_{0}$ diterima dan $\mathrm{H}_{1}$ ditolak, artinya variabel independen tidak berpengaruh terhadap variabel dependen. Terakhir, koefisien determinasi dilakukan untuk mengetahui persentase pengaruh variasi variabel independen terhadap perubahan variabel dependen. 
Persamaan regresi dalam penelitian ini yaitu:

$\mathrm{Q}=\alpha+\beta_{1} \mathrm{ROA}+\beta_{2} \mathrm{FCF}+\beta_{3}$ Size $+\varepsilon$

Keterangan

$\mathrm{Q}=$ Nilai Perusahaan

$\alpha \quad=$ Konstana

$\beta_{1}-\beta_{3}=$ Koefisien Regresi

ROA = Profitabilitas

$\mathrm{FCF}=$ Free Cash Flow

Size = Ukuran Perusahaan

e $\quad=$ Error

\section{HASIL DAN PEMBAHASAN}

Statistik deskriptif digunakan untuk memberikan deskripsi suatu data yang dilihat dari rata-rata (mean), simpangan baku (standar deviation), maksimum, dan minimum. Berdasarkan pemilihan sampel diperoleh 24 perusahaan consumer goods. Tabel 1 berikut ini menunjukkan hasil analisis statistik deskriptif.

Tabel 1.

Analisis Statistik Deskriptif

\begin{tabular}{lccccc}
\hline & N & Minimum & Maksimum & Rata-rata & Simpangan baku \\
\hline ROA & 120 & 0,410 & 62,000 & 15,878 & 13,498 \\
FCF & 120 & $-4,710$ & 0,690 & $-0,247$ & 0,507 \\
SIZE & 120 & 25,190 & 32,150 & 28,512 & 1,753 \\
Q & 120 & 0,000 & 21,080 & 3,756 & 4,271 \\
Valid N (listwise) & 120 & & & & \\
Sumber : Data diolah, 2017 & & & &
\end{tabular}

Berdasarkan Tabel 1. profitabilitas menunjukkan nilai rata-rata sebesar 15,878 , ini artinya ada kecenderungan nilai rata-rata mendekati nilai maksimum. Hal ini berarti bahwa rata-rata perusahaan memiliki return on assets yang tinggi. Nilai simpangan baku sebesar 13,498 lebih kecil daripada nilai rata-rata. Hal ini menunjukkan bahwa sebaran data return on assets sudah merata atau rentang data satu dengan data lainnya tidak tergolong tinggi. Nilai maksimum sebesar 62,000 dan nilai minimum sebesar 0,410 . 
Berdasarkan Tabel 1 diatas, free cash flow menunjukkan nilai rata-rata sebesar -0,247 ini artinya ada kecenderungan nilai rata-rata mendekati nilai minimum. Ada dua kemungkinan terhadap sampel perusahaan yang memiliki nilai free cash flow negatif yaitu jika nilai free cash flow negatif karena Net Operating Profit After Tax (NOPAT) negatif, maka hal tersebut menunjukkan bahwa ada kemungkinan perusahaan mengalami masalah operasi dan jika nilai free cash flow negatif, tingkat pertumbuhan perusahaan tinggi, dan NOPAT positif menunjukkan bahwa perusahaan banyak berinvestasi dalam aset operasi untuk mendukung pertumbuhan cepat (Husnan, 2002:87). Nilai simpangan baku sebesar 0,507 lebih besar daripada nilai rata-rata. Hal ini menunjukkan bahwa sebaran data free cash flow memiliki rentang data satu dengan lainnya tergolong cukup tinggi. Nilai maksimum sebesar 0,690 dan nilai minimum sebesar $-4,710$.

Berdasarkan Tabel 1, ukuran perusahaan menunjukkan nilai rata-rata 28,512 ini artinya ada kecenderungan nilai rata-rata mendekati nilai maksimum. Hal ini berarti bahwa rata-rata perusahaan memiliki ukuran perusahaan yang besar. Nilai simpangan baku sebesar 1,753 lebih kecil daripada nilai rata-rata. Hal ini menunjukkan bahwa sebaran data ukuran perusahaan sudah merata atau rentang data satu dengan lainnya tergolong tidak cukup tinggi. Nilai maksimum sebesar 32,150 dan nilai minimum sebesar 25,190.

Berdasarkan Tabel 1, nilai perusahaan menunjukkan nilai rata-rata 3,756 ini artinya ada kecenderungan nilai rata-rata mendekati nilai minimum. Hal ini berarti bahwa rata-rata perusahaan memiliki nilai perusahaan yang rendah. Nilai simpangan baku sebesar 4,271 lebih besar daripada nilai rata-rata. Hal ini 
menunjukkan bahwa sebaran data nilai perusahaan memiliki rentang data satu dengan lainnya tergolong cukup tinggi. Nilai maksimum sebesar 21,080 dan nilai minimum sebesar 0,000 .

Uji normalitas diuji dengan menggunakan uji statistik One-Parametrik Kolmogorov-Smirnov (K-S). Apabila nilai Asymp. Sig (2-tailed) $>\alpha(0,05)$ maka dapat dikatakan bahwa variabel memenuhi asumsi normalitas. Berdasarkan hasil uji normalitas pada penelitian ini diperoleh nilai Asymp. Sig (2-tailed) sebesar 0,060 yakni lebih besar dari $\alpha(0,05)$ yang artinya bahwa seluruh data dapat dikatakan berdistribusi normal.

Uji multikolinearitas bertujuan untuk menguji apakah model regresi ditemukan adanya korelasi antar variabel bebas (independen). Model dapat dikatakan bebas dari masalah multikolinearitas apabila nilai tolerance lebih besar dari $10 \%(0,1)$ atau VIF kurang dari 10 . Berdasarkan hasil uji multikolinearitas diperoleh nilai tolerance ROA sebesar 0,830, FCF sebesar 0,825, dan Size sebesar 0.961. Hal ini menunjukkan bahwa model dapat dikatakan bebas dari masalah multikolinieritas.

Uji heteroskedastisitas bertujuan untuk menguji apakah dalam model regresi terjadi ketidaksamaan varian dari residual satu pengamatan ke pengamatan yang lain. Uji Glesjer Test dilakukan untuk mendeteksi masalah tersebut, jika nilai Asymp. Sig (2-tailed) $>\alpha(0,05)$, maka tidak terjadi gejala heteroskedastisitas. Hasil uji heteroskedastisitas diperoleh nilai signifikansi ROA sebesar 0,080, FCF sebesar 0,141 dan Size sebesar 0,501, ini artinya bahwa seluruh variabel tidak mengandung gejala heteroskedastisitas. 
Berdasarkan hasil uji autokorelasi pada penelitian ini diperoleh nilai dL sebesar 1,6513 dan dU sebesar 1,7536, maka nilai D-W 1,934 lebih besar dari batas atas $(\mathrm{du})=1,7536$ dan kurang dari 4-batas atas $(4-\mathrm{du})=2,2464$ maka kesimpulannya adalah $\mathrm{d}_{\mathrm{u}}<\mathrm{DW}<4-\mathrm{d}_{\mathrm{u}}$ dengan hasil keputusan tidak terjadi autokorelasi. Berdasarkan uji asumsi klasik yang dilakukan diperoleh hasil bahwa data telah terdistribusi normal, bebas dari multikolinearitas, heteroskedastisitas dan autokorelasi maka dapat disimpulkan bahwa model regresi penelitian ini telah lolos uji asumsi klasik.

Tabel 2.

Hasil Uji Kelayakan Model (Uji -F)

\begin{tabular}{llccccc}
\hline Model & & Sum of Squares & Df & Mean Square & F & Sig. \\
\hline \multirow{3}{*}{1} & Regression & 1343,842 & 3 & 447,947 & 62,796 & $0,000^{\mathrm{b}}$ \\
& Residual & 827,465 & 116 & 7,133 & & \\
& Total & 2171,307 & 119 & & & \\
\hline
\end{tabular}
Sumber : Data diolah, 2017

Berdasarkan Tabel 2. dapat diketahui $\mathrm{F}_{\text {hitung }}$ sebesar 62,796 dan signifikansi (p-value) sebesar 0,000 . Oleh karena nilai signifikansi $0,000<\alpha(0,05)$, hal ini berarti model yang dibentuk dari ketiga variabel bebas tersebut telah layak atau fit untuk digunakan dalam interpretasi model.

Tabel 3.

Hasil Analisis Regresi Linear Berganda

\begin{tabular}{|c|c|c|c|c|c|c|}
\hline & \multirow[t]{2}{*}{ Model } & \multicolumn{2}{|c|}{$\begin{array}{c}\text { Unstandardized } \\
\text { Coefficients }\end{array}$} & \multirow{2}{*}{$\begin{array}{c}\begin{array}{c}\text { Standardized } \\
\text { Coefficients }\end{array} \\
\text { Beta } \\
\end{array}$} & \multirow[t]{2}{*}{$\mathbf{t}$} & \multirow[t]{2}{*}{ Sig. } \\
\hline & & B & Std. Error & & & \\
\hline \multirow{4}{*}{1} & (Constant) & $-13,748$ & 4,073 & & $-3,375$ & 0,001 \\
\hline & ROA & 0,220 & 0,020 & 0,694 & 11,033 & 0,000 \\
\hline & $\mathrm{FCF}$ & 0,614 & 0,531 & 0,073 & 1,155 & 0,250 \\
\hline & SIZE & 0,497 & 0,142 & 0,204 & 3,489 & 0,001 \\
\hline
\end{tabular}

Sumber : Hasil Uji SPSS (2017)

Berdasarkan Tabel 3. diperoleh nilai konstanta $(\alpha)$ sebesar -13,748 berarti apabila ROA, FCF, dan SIZE bernilai 0, maka nilai perusahaan akan bernilai - 
13,748 satuan. Nilai koefisien ROA $\left(\beta_{1}\right)$ sebesar 0,220 , berarti apabila return on asset bertambah sebanyak satu satuan dengan anggapan variabel lainnya konstan, maka nilai perusahaan akan meningkat sebesar 0,220 satuan. Nilai koefisien FCF $\left(\beta_{2}\right)$ sebesar 0,614 , berarti free cash flow bertambah sebanyak satu satuan dengan anggapan variabel lainnya konstan, maka nilai perusahaan meningkat sebesar rata-rata 0,614 satuan. Nilai koefisien $\operatorname{SIZE}\left(\beta_{3}\right)$ sebesar 0,497 , berarti ukuran perusahaan bertambah sebanyak satu satuan dengan anggapan variabel lainnya konstan, maka nilai perusahaan meningkat sebesar rata-rata 0,497 satuan.

Uji hipotesis digunakan untuk menguji tingkat signifikansi pengaruh variabel independen terhadap variabel dependen secara parsial. Berdasarkan Tabel 3 diperoleh hasil nilai signifikansi variabel ROA adalah sebesar $0,000<\alpha(0,05)$, maka $\mathrm{H}_{0}$ ditolak dan $\mathrm{H}_{1}$ diterima. Hasil ini menunjukkan bahwa secara parsial profitabilitas berpengaruh positif terhadap nilai perusahaan.

Berdasarkan Tabel 3. diperoleh hasilnilai signifikansi variabel FCF adalah sebesar $0,250>\alpha(0,05)$, maka Ho diterima dan $\mathrm{H}_{2}$ ditolak. Ini berarti bahwa secara parsial free cash flow tidak berpengaruh terhadap nilai perusahaan. Berdasarkan Tabel 3. diperoleh hasil nilai signifikansi variabel SIZE sebesar $0,001>\alpha(0,05)$, maka Ho ditolak dan $\mathrm{H}_{3}$ diterima. Ini berarti bahwa secara parsial ukuran perusahaan berpengaruh positif terhadap nilai perusahaan.

Tabel 4.

Hasil Uji Koefisien Determinasi

\begin{tabular}{ccccc}
\hline Model & R & R Square & $\begin{array}{c}\text { Adjusted R } \\
\text { Square }\end{array}$ & $\begin{array}{c}\text { Std. Error of the } \\
\text { Estimate }\end{array}$ \\
\hline 1 & $0,787^{\mathrm{a}}$ & 0,619 & 0,609 & 2,670 \\
\hline Sumber : Hasil Uji SPSS (2017) & & & &
\end{tabular}


Berdasarkan Tabel 4. diatas menunjukkan nilai Adjusted R Square sebesar 0,609 berarti bahwa 60,9 persen variabel nilai perusahaan dapat dijelaskan oleh variabel profitabilitas, free cash flow, dan ukuran perusahaan, sedangkan sisanya sebesar 39,1 persen dipengaruhi oleh variabel-variabel lain diluar model.

Hasil analisis regresi linier berganda pada Tabel 3. menunjukkan bahwa variable profitabilitas berpengaruh positif terhadap nilai perusahaan. Penelitian ini sejalan dengan penelitian yang dilakukan oleh Chen dan Chen (2011), Pratama (2016), Garmayuni (2015), Ghosh dan Ghosh (2008), dan Dwipayana (2016) yang menyatakan bahwa profitabilitas yang diproksikan dengan return on assets berpengaruh terhadap nilai perusahaan. Hasil ini juga mendukung signalling theory, dimana pelaporan informasi keuangan terkait kinerja perusahaan dapat meningkatkan nilai perusahaan. Profitabilitas yang tinggi akan memberikan sinyal kepada investor bahwa perusahaan memiliki prospek yang baik dimasa mendatang (Kusumayanti, 2016). Semakin besar return on asset, maka tingkat keuntungan yang dihasilkan perusahaan dari pengelolaan asetnya semakin besar, dengan pengelolaan aset yang semakin efektif dan efisien maka tingkat kepercayaan investor terhadap perusahaan akan meningkat yang nantinya akan meningkatkan nilai perusahaan melalui peningkatan harga saham (Ang, 1997).

Hasil analisis regresi linier berganda pada Tabel 3. menunjukkan bahwa variabel free cash flow tidak berpengaruh terhadap nilai perusahaan. Hasil penelitian ini sejalan dengan penelitian yang pernah dilakukan oleh Yudianti (2005), Naini (2014) serta Arieska dan Gunawan (2011). Hasil yang tidak signifikan dikarenakan adanya kekhawatiran dari pemegang saham bahwa free 
cash flow yang ada diperusahaan akan digunakan oleh manajer untuk melakukan tindakan oportunistik guna memperkaya diri sendiri (Arieska dan Gunawan, 2011). Ketika perusahaan memiliki tingkat free cash flow yang tinggi namun tidak tersedia proyek yang menguntungkan maka akan timbul kecenderungan manajemen untuk melakukan tindakan penyalahgunaan free cash flow dengan tindakan-tindakan oportunistik seperti melakukan alokasi sumber daya yang tidak efisien serta adanya perilaku-perilaku konsumtif yang berlebihan dimana hal-hal tersebut tidak sejalan dengan peningkatan nilai perusahaan tetapi akan membebankan pemegang saham (Yasa dan Dewi, 2016).

Hasil analisis regresi linier berganda pada Tabel 3. menunjukkan bahwa variable ukuran perusahaan berpengaruh positif terhadap nilai perusahaan. Hasil penelitian ini sejalan dengan penelitian yang pernah dilakukan oleh Analisa (2011), Armadi (2016), dan Risqia (2013) yang menyatakan bahwa ukuran perusahaan berpengaruh positif terhadap nilai perusahaan. Hasil ini mendukung signalling theory dimana ukuran perusahaan yang besar maka akan meningkatkan nilai perusahaan. Hal ini karena perusahaan besar memiliki total aset yang besar sehingga cenderung memiliki kondisi keuangan yang lebih stabil dan lebih mudah mendapatkan sumber pendanaan sehingga akan lebih menarik bagi investor untuk membeli sahamnya sehingga akan mendorong naiknya nilai perusahaan.

\section{SIMPULAN DAN SARAN}

Berdasarkan hasil analisis, maka dapat disimpulkan profitabilitas berpengaruh positif pada nilai perusahaan, karena semakin besar profitabilitas maka semakin efektif dan efisien pengelolaan asetnya yang akan meningkatkan 
nilai perusahaan. Ukuran perusahaan berpengaruh positif pada nilai perusahaan, karena semakin besar ukuran perusahaan maka nilai perusahaannya akan meningkat. Sedangkan variabel free cash flow tidak berpengaruh pada nilai perusahaan, berdasarkan hasil penelitian ini free cash flow tidak memiliki peran dalam meningkatkan nilai perusahaan.

Saran yang dapat disampaikan bagi pihak manajemen perusahaanperusahaan consumer goods disarankan untuk memperhatikan variabel profitabilitas dan ukuran perusahaan, karena hasil penelitian ini menunjukkan variabel profitabilitas dan ukuran perusahaan memiliki pengaruh positif pada nilai perusahaan. Bagi peneliti selanjutnya, dapat menguji kembali pengaruh free cash flow pada nilai perusahaan dengan menggunakan sampel yang berbeda dan memperpanjang periode waktu penelitian sehingga akan mendapatkan perbandingan hasil.

\section{REFERENSI}

Al Zararee, Abdul Nafea and Abdulrahman Al-Azzawi. 2014. The Impact of Free Cash Flow on Market Value Firm. Global Review of Accounting and Finance, 5 (2); pg : 56-63

Analisa, Yangs. 2011. Pengaruh Ukuran Perusahaan, Leverage, Profitabilitas, dan Kebijakan Dividen Terhadap Nilai Perusahaan (Studi Empiris Pada Perusahaan Manufaktur yang Terdaftar Di Bursa Efek Indonesia Tahun 2006-2008). Skripsi. Fakultas Ekonomi Universitas Diponegoro

Andini, Ni Wayan Lady, dan Ni Gusti Putu Wirawati. 2014. Pengaruh Cash Flow Pada Kinerja Keuangan Dan Implikasinya Pada Nilai Perusahaan Manufaktur Di Bursa Efek Indonesia. E-Jurnal Akuntansi Universitas Udayana, 7(1); h: 107-121.

Ang, Robert. 1997. Buku Pintar Pasar Modal Indonesia.Media Staff Indonesia. Jakarta 
Arfan, Muhamad. 2013. Nilai Perusahaan Dalam Kaitannya Dengan Arus Kas Bebas Dan Pertumbuhan Perusahaan. Jurnal Telaah dan Riset Akuntansi Universitas Syiah Kuala, 6(1); h:14 - 30

Arieska, Metha dan Barbara Gunawan.2011. Pengaruh Aliran Kas Bebas dan Keputusan Pendanaan terhadap Nilai Perusahaan dengan Set Kesempatan Investasi dan Kebijakan Dividen sebagai Variabel Mediasi.Jurnal Akuntansi dan Keuangan 13(1); h:13-23.

Armadi, I Wayan. 2016. Pengaruh Profitabilitas, Leverage, dan Ukuran Perusahaan Pada Nilai Perusahaan Melalui Pengungkapan Tanggung Jawab Sosial. E-Jurnal Akuntansi Universitas Udayana, 17(1); h: 233-256.

Brigham, Eugene dan Joel Houston. 2006. Manajemen Keuangan. Buku kedua.Edisi kesepuluh. Jakarta: Erlangga.

Chen, Li-Ju, and Chen, Shun-Yu. 2011. The Influence of Profitability on Firm Value With Capital Structure as The Mediator and Firm Size and Industry as Moderators. Investment management and Fiancial Innovations, 8(3). Pp:121-129

Dewi, Ayu Sri Mahatma. 2013. Pengaruh Struktur Modal, Profitabilitas, dan Ukuran Perusahaan Terhadap Nilai Perusahaan. E-Jurnal Akuntansi Universitas Udayana, 4(2); h: 358-372.

Dewi, Ida Ayu Made Candra. 2016. Pengaruh Earnings Management dan Kebijakan Dividen Pada Nilai Perusahaan dengan Free Cash Flow sebagai Pemoderasi. Skripsi. Sarjana Jurusan Akuntansi pada Fakultas Ekonomi dan Bisnis Universitas Udayana, Denpasar.

Dwipayana, Made Agus Teja. 2016. Pengaruh Debt to Asset Ratio, Dividend Payout Ratio, dan Return On Assets Terhadap Nilai Perusahaan. E-Jurnal Akuntansi Universitas Udayana, 17(3); h: 2008-2035.

Garmayuni, Rindu Rika. 2015. The Effect of Intangible Asset, Financial Performance and Financial Policies on The Firm Value. International Journal of Scientific and Technology Research, 4(1), pp: 202-212.

Ghosh, Saurabh, and Ghosh, A. 2008. Do Leverage, Dividend Policy, and Profitability Influence the Future Value of Firm ?Evidence from India. pp:1-19

Ghozali, Imam. 2016. Aplikasi Analisis Analisis Multivariete dengan Program IBM SPSS 21. Semarang: Badan Penerbit Universitas Diponegoro 
Gitman, Lawrence J. 2009.Principles of Managerial Finance. United States: Pearson Addison Wesley.

Gregory, A dan Yuan-Hsin Wang. 2010. Cash Inquirers: Free Cash Flow Shareholder Monitoring and Shareholder Return. Discussion Paper University of Exerter, UK. No. 10/07

Herawati, Titin. 2013. Pengaruh Kebijakan Dividen, Kebijakan Hutang dan Profitabilitas Terhadap Nilai Perusahaan. E-journal UNP, 2(2). h:1-18.

Husnan, Suad. 2002. Dasar-dasar Teori Portofolio dan Analisis Sekuritas Edisi Ketiga. Yogyakarta: UPP AMP YKPN

Jensen, M.C. 1986. Agency of Free Cash Flow, Corporate Finance, and Takeovers.American Economics Review, 76, May 1986, pg:232-329

Jogiyanto H, M. 2010. Teori Potofolio dan Analisis Investasi Edisi Ketujuh.Yogyakarta : BPFE- Yogyakarta.

Kieso, Donald E., Jerry J. Weygandt, Terry D. Warfield. 2014. Intermediate Accounting Second Edition IFRS Edition. Penerbit : Wiley Plus

Kusumayanti, Ni Ketut Ratna. 2016. Corporate Social Responsibility Sebagai Pemediasi Pengaruh Ukuran Perusahaan, Profiabilitas, dan Leverage Terhadap Pada Perusahaan. E-Jurnal Akuntansi Universitas Udayana, 15(1); h: 549-583.

Naini, Dwi Ismiwatis. 2014. Pengaruh Free Cash Flow dan Kepemiikan Institusional Terhadap Kebijakan Hutang dan Nilai Perusahaan. Jurnal Ilmu dan Riset Akuntansi, 3(4); h: 1-17

Nurhayati, Mafizatun. 2013. Profitabilitas, Likuiditas, dan Ukuran Perusahaan Pengaruhnya Terhadap Kebijakan Dividen dan Nilai Perusahaan Sektor Non Jasa. Jurnal Keuangan dan Bisnis. 5(2); h:144-153

Pratama, I Gede Gora Wira.2016. Pengaruh Struktur Modal dan Profitabilitas Terhadap Nilai Perusahaan Dengan Kepemilikan Manajerial Sebagai Pemoderasi.E-Jurnal Akuntansi Universitas Udayana, 15(3); h:1796-1825.

Risqia, D.A, Aisjah S., dan Sumiati. 2013. Effect Of Managerial Ownership, Financial Leverage, Profitability, Firm Size, and Investment Opportunity on Dividend Policy and Firm Value, IISTE Vol. 8, No. 1 h: 23-40

Ross, S.A., R.W. Westerfield, dan B. D. Jordan. 2000. Fundamentals of Corporate Finance. Fifth Edition, Irwin McGraw Hill. Boston. 
Rudangga, I Gusti Ngurah Gede. 2016. Pengaruh Ukuran Perusahaan, Leverage, dan Profitabilitas Terhadap Nilai Perusahaan. E-Jurnal Akuntansi Universitas Udayana, 5(7); h: 4394-4422

Salvatore, Dominick. 2005. Managerial Economics. Fifth Edition. Singapore: Thomson Learning.

Smithers, Andrew dan Wright, Stephen. (2008). Valuing Wall Street. McGraw Hill.

Suartawan, I Gusti Putu Adi dan Gerianta Wirawan Yasa. 2016. Pengaruh Investment Opportunity Set dan Free Cash Flow pada Kebijakan Dividen dan Nilai Perusahaan. E-Jurnal Akuntansi Universitas Udayana, 11(2); h: 63-73.

Suharli, Michaell. 2006. Studi Empiris Terhadap Faktor yang Mempengaruhi Nilai Perusahaan Go Publik di Indonesia.Jurnal Maksi. 6(1).

Sujoko, dan Soebianto, Ugy. 2007. Pengaruh Struktur Kepemilikan Saham, Leverage, Faktor Intern dan Faktor Ekstern Terhadap Nilai Perusahaan (Studi Empiris pada Perusahaan Manufakturdan Non Manufaktur di Bursa Efek Jakarta). Jurnal Manajemen dan Kewirausahaan, 9(1), h: 41-48

Sugiyono. 2012. Metode Penelitian Bisnis. Bandung. Penerbit : Alfabeta

2014.Metode Penelitian Bisnis(Pendekatan Kuantitatif, Kualitatif, dan R\&D). Bandung. Penerbit : Alfabeta

Tommy, P. 2010. Konsentrasi Kepemilikan Saham, Risiko Perusahaan, Likuiditas Saham, Arus Kas, dan Nilai Perusahaan. Jurnal Keuangan dan Perbankan 14 edisi khusus: 641-651

Vogt, Stephen C. And Joseph D. Vu. 2000. Free Cash Flow ang Long-Run Firm Value: Evidence From The Value Line Investment Survey. Journal of Managerial Issues, 12(2), pg:188

Wang, George Yungchih. 2010. The Impacts Free Cash Flows and Agency Costs on Firm Performance. Journal Service Science \& Management.Vol.3, pg: 408- 418,Department of International Business, National Kaohsiung University of Applied Sciences, Kaohsiung, Taiwan, China.

Wardani, R. A. K. Dan B. Siregar. 2009. Pengaruh Aliran Kas Bebas Terhadap Nilai Pemegang Saham Dengan Set Kesempatan Investasi dan Dividen Sebagai Variabel Moderator. Jurnal Akuntansi dan Manajemen, 20(3): h:157-174 
Wiagustini, Ni Luh Putu. 2010. Manajemen Keuangan. Denpasar. Udayana University Press.

Wolk, et. al. 2001. "Signalling, Agency Theory, Accounting Policy Choice." Accounting and Business Research. Vol. 18 No. 69:47-56

Yasa, Gerianta Wirawan dan Ni Luh Ayu Sukrisna Dewi. 2016. Free Cash Flow, Outsider Ownership, Leverage, dan Kebijakan Dividen Terhadap Kos Keagenan. Jurnal Akuntansi Universitas Tarumanagara, 20(3); h: 389-409

Yudianti, F. N. 2005. Analisis Pengaruh Set Kesempatan Investasi, Manajemen Laba, Leverage, dan Dividen terhadap Hubungan antara Aliran Kas Bebas dan Nilai Pemegang Saham.Disertasi. Universitas Gajah Mada.

IDX Statistic Books.2010-2015. www.idx.co.id. Diunduh pada tanggal 8 Mei 2017 